\title{
Differences in the salivary inorganic ions levels and salivary flow rate of the periodontitis and non-periodontitis patients
}

\author{
Rizki Amalina ${ }^{1 *}$, Mahdalena ${ }^{1}$, Grahita Aditya ${ }^{2}$ \\ ${ }^{1}$ Department of Oral Biology, Faculty of Dentistry Sultan Agung Islamic University, Indonesia \\ ${ }^{2}$ Department of Orthodontics, Faculty of Dentistry Sultan Agung Islamic University, Indonesia
}

\begin{abstract}
Introduction: Saliva contains numerous proteins and electrolytes that may serve as biomarkers of pathological conditions, including periodontitis. Saliva flow also influenced by pathological conditions, such as periodontitis. Therefore, saliva analysis, as one of the biomarker source needs to be examined. This study was aimed to analyse the differences salivary inorganic ions levels (calcium, phosphate, and bicarbonate) and salivary flow rate in periodontitis and non-periodontitis patients. Methods: This research was analytic-observational using two groups, the healthy periodontal group consisting of 21 people (PI scores between $0-0.2$ ) and the periodontitis group consisting of 21 people (PI scores between 0.7-8.0). Unstimulated saliva was collected using a passive drolling method. The calcium, phosphate and bicarbonate levels in the saliva were analysed using UV/Vis spectrophotometers. Results: Calcium, phosphate and bicarbonate levels in saliva were different between groups. Salivary flow rate also different between groups. There was a significant difference $(p=0.00)$ in the calcium, phosphate and bicarbonate levels between groups (t-test), and also significantly different $(p=0.000)$ salivary flow rate between groups. The higher the salivary flow rate, the higher the levels of calcium, phosphate and bicarbonate would be. Conclusion: Periodontitis condition increases the level of salivary inorganic ions and salivary flow rate because of periodontal inflammation. This inflammation mainly because of plaque deposition and calculus. Increased level of inorganic ions in the saliva such as calcium, phosphate, and bicarbonate, and also the salivary flow rate indicates the existence of a periodontal disease.
\end{abstract}

Keywords: Bicarbonate, calcium, periodontitis, phosphate, salivary flow rate.

p-ISSN: 1979-0201; e-ISSN: 2549-6212; Available from: http://jurnal.unpad.ac.id/pjd/article/view/21201

DOI: $10.24198 /$ pjd.vol32no2.21201

Submission: Mar 30, 2019; Accepted: Jul 31, 2020; Published online: Jul 31, 2020

\section{INTRODUCTION}

Based on the data of Indonesia Basic Health Research, 25.9\% Indonesian citizens still possess little awareness towards of oral and dental health. ${ }^{1}$ Data from the Ministry of Health of the Republic of Indonesia in 2012 also showed that periodontitis is the second most occurring oral disease. ${ }^{2}$ 
Periodontitis is one of the factors causing tooth loss. ${ }^{3}$ Severe periodontitis could systemically affect body health because it may increase risks of atherosclerosis, diabetes, rheumatoid arthritis, and so forth. ${ }^{3}$ Periodontitis is an inflammatory disease caused by biofilm bacteria and may affect the integrity of teeth supporting oral cavity tissues (periodontal ligament, gingiva and alveolar bone) or often called periodontium. ${ }^{4}$

Saliva produced by salivary gland contains lots of proteins/peptides, electrolytes and hormones, serving as a source of a potential biomarker to monitor any changes during a pathological circumstance. ${ }^{5}$ During the last decade, research on potential saliva as a source of useful biomarkers for early detection in clinical diagnostics and prognostics has advanced. Saliva collection has become more accessible, noninvasive and cheap, especially for a significant population screening. ${ }^{6}$

Numerous pathological and physiological conditions could modify saliva production and secretion quantitatively and qualitatively. One of them may affect acinar cells in the salivary gland which secrete fluids containing water, electrolytes (calcium, phosphate, magnesium, etc.), mucus and enzyme (lactoferrin, lactoperoxidase). ${ }^{6}$ Adequate saliva secretion is necessary for maintaining good oral hygiene. ${ }^{3}$ Changes in saliva composition and flow rate may affect the integrity of soft and hard tissues of oral cavity. ${ }^{7}$ Salivary flow rate, buffer capacity, $\mathrm{pH}$, calcium, phosphate and fluoride ions are essential factors in forming calculus and development of the periodontal disease. ${ }^{3}$ Concerning periodontal health, saliva plays a role in two ways, pellicle and plaque formation. At the last stage of plaque formation, salivary inorganic ion levels play a critical role. It becomes part of the gel-like consistency of plaque and begins to influence its mineralisation. Mineral precipitate results from a local rise in the degree of saturation of calcium and phosphates in saliva due to increase of $\mathrm{pH}$ saliva. It is because bicarbonate and phosphate act directly as buffers once they diffused into the plaque. ${ }^{7}$

Extent research showed that periodontitis is related to an increment in calcium level in saliva. ${ }^{8}$ Salivary calcium is an essential factor in forming supra and subgingival calculus. ${ }^{9}$ In future, the use of saliva as an aid to diagnose periodontal disease and predict periodontal treatment will be needed. ${ }^{10}$ The traditional approach in clinical criteria is often insufficient for monitoring the response to treatment or for measuring the degree of susceptibility to future disease progression. Saliva as a mirror of oral and systemic health is a valuable source for clinically relevant information because it contains biomarkers specific for the unique aspects of periodontal diseases. ${ }^{11}$ This research was aimed to analyse the differences salivary inorganic ions levels (calcium, phosphate, and bicarbonate) and salivary flow rate in periodontitis and non-periodontitis patients.

\section{METHODS}

This research was analytic-observational with cross-sectional approach. Ethical approval was obtained from the Faculty of Dentistry, Sultan Agung Islamic University, with registration number of 004/B.1-KEPK/SA-FKG/I/2018. Inclusion criteria for the subjects in this research were: no systemic disease history, age ranged between 20-40 years, did not use mouthwash, did not pregnant, did not in orthodontic treatment, did not have a denture, and did not engage in periodontal treatment. Exclusion criteria is uncooperative respondent.

Respondents consisted of 42 people, grouped based on the condition of periodontal tissues by oral examination, including the number of existing teeth in the oral cavity, levels of attachment loss, bleeding during probing and the depth of periodontal pockets. Furthermore, the subjects were categorised according to Russel's modified Periodontal Index (as seen in Table 1). This index was based on the progressivity of gingival dan periodontal inflammation. ${ }^{3}$

Respondents were then divided into healthy periodontal and periodontitis groups. The healthy periodontal group consisted of 21 people whose

Table 1. Russel's modified Periodontal Index (PI)

\begin{tabular}{cl}
\hline Score & \multicolumn{1}{c}{ criteria } \\
\hline 0 & No inflammation \\
1 & Mild gingivitis \\
2 & Gingivitis \\
4 & Alveolar bone resorption \\
6 & Periodontal pocket with horizontal bone resorption \\
8 & Advance periodontitis. Bone resorpstion more than \\
& half root/ infrabony pocket \\
\hline
\end{tabular}


PI scores were between 0-0.2, whereas the periodontitis group consisted of 21 people with $\mathrm{PI}$ scores are between 0.7-8.0.

Saliva collection was performed at 9-12 a.m at Sultan Agung Dental Hospital after the patients were instructed to fast an hour earlier. The method used was the unstimulated saliva with the passive drolling method, in which a patient would sit erect with his/her head tilted slightly, allowing saliva to flow passively in a container. The accumulated samples were sent to the laboratory to be tested its level of salivary calcium, phosphate, and bicarbonate using UV/Vis spectrophotometers. Data analysis was performed using Independent t-test for comparison of the inorganic ion levels between healthy periodontal group and periodontitis group, also comparison of the salivary flow rate between healthy periodontal group and periodontitis group.

\section{RESULTS}

The result of salivary flow rate measurement is as follows:

Table 2. Salivary flow rate

\begin{tabular}{lcccc}
\hline $\begin{array}{l}\text { Group } \\
(\text { Sex })\end{array}$ & $\mathrm{N}$ & $\begin{array}{l}\text { Healthy periodontal } \\
(\mathrm{ml} / \text { minute) }\end{array}$ & $\mathrm{N}$ & $\begin{array}{l}\text { Periodontitis } \\
(\mathrm{ml} / \text { minute })\end{array}$ \\
\hline Male & 8 & \pm 0.31 & 12 & \pm 0.78 \\
Female & 13 & \pm 0.22 & 9 & \pm 0.58 \\
\hline $\begin{array}{l}\text { Total } \\
\text { average }\end{array}$ & 21 & \pm 0.24 & 21 & \pm 0.67 \\
\hline
\end{tabular}

Table 2 indicates that the average salivary flow rate of the periodontitis group $(0.67 \mathrm{ml} /$ minute) was higher than the healthy periodontal group $(0.24 \mathrm{ml} /$ minute). The data also showed that the average salivary flow rate of males in the healthy periodontal group was higher $(0.31$ $\mathrm{ml} /$ minute) than females $(0.22 \mathrm{ml} /$ minute $)$ and the average salivary rate of males in the periodontitis group was also higher $(0.78 \mathrm{ml} /$ minute) than females $(0.58 \mathrm{ml} /$ minute $)$. Overall, the salivary flow rate of the periodontitis group was higher than the healthy periodontal group.

Data in Table 3 indicates that the phosphate level of periodontitis patients $(5.45 \mathrm{mmol} / \mathrm{L})$ was higher than the healthy respondents $(3.15$ $\mathrm{mmol} / \mathrm{L}$ ). The calcium level of periodontitis patients $(4.52 \mathrm{mmol} / \mathrm{L})$ was higher than the
Table 3. The average of calcium, phosphate and bicarbonate levels in saliva

\begin{tabular}{llc}
\hline Inorganic contents & $\begin{array}{l}\text { Periodontal tissue } \\
\text { condition }\end{array}$ & $\begin{array}{c}\text { Mean } \\
(\mathrm{mmol} / \mathrm{L})\end{array}$ \\
\hline Phosphate $\left(\mathrm{PO}_{4}\right)$ & Healthy periodontal & 3.15 \\
& Periodontitis & 5.45 \\
Calcium $(\mathrm{Ca})$ & Healthy periodontal & 1.74 \\
& Periodontitis & 4.52 \\
Bicarbonate $\left(\mathrm{HNO}_{3}\right)$ & Healthy periodontal & 7.04 \\
& Periodontitis & 37.85 \\
\hline
\end{tabular}

healthy respondents $(1.74 \mathrm{mmol} / \mathrm{L})$, and the bicarbonate level of periodontitis patients (37.85 $\mathrm{mmol} / \mathrm{L}$ ) was higher than the healthy respondents (7.04 mmol/L).

The results of normality and homogeneity tests suggested that the data were normally distributed and homogeneous. Thus, an independent $\mathrm{t}$-test was performed in advance.

Table 4. The result of comparison test on ion levels between the healthy periodontal group and the periodontitis group ( $t$-test); and correlation between salivary flow rate and the inorganic levels (Pearson test)

\begin{tabular}{lllcc}
\hline Ion & T & Df & Sig (T-test) & Sig (Pearson test) \\
\hline Calcium & -8.845 & 40 & 0.000 & 0.000 \\
Phosphate & -9.769 & 40 & 0.000 & 0.000 \\
Bicarbonate & -19.129 & 40 & 0.000 & 0.000 \\
\hline
\end{tabular}

Based on the independent $\mathrm{t}$-test result, the $\mathrm{p}$-value $=0.00$, which can be concluded that the levels of calcium, phosphate, and bicarbonate in the periodontitis patients were significantly different from the healthy periodontal respondents.

From the data presented in Table 4 can be found that the correlation between salivary flow rate and the inorganic levels using the Pearson test resulting in the $p$-value $=0.000$, meaning that there was a significant positive correlation, thus, there was a relationship between the salivary flow rate and inorganic levels. The higher the salivary flow rate, the higher the levels of calcium, phosphate, and bicarbonate in the saliva will be found.

Table 5. Comparison test (t-test) result of the salivary flow rate between periodontitis group and healthy group

\begin{tabular}{lc}
\hline \multicolumn{1}{c}{ Salivary flow rate } & Sig \\
\hline $\begin{array}{l}\text { Periodontitis group } \\
\text { Healthy group }\end{array}$ & 0,000 \\
\hline
\end{tabular}


The independent $t$-test result suggested that the salivary flow rate between the periodontitis group and the healthy group resulting in the $\mathrm{p}$-value $=0.00$, suggesting that there was a significant difference between both groups.

\section{DISCUSSION}

Saliva is a bodily fluid excreted by saliva glands in the oral cavity. Saliva plays a role in forming plaque, providing lubricating effects on the oral cavity and maintain the integrity of oral mucosa. ${ }^{12}$ An analysis of saliva may contribute to diagnostics and prognosis towards periodontal tissue disease based on organic and inorganic compositions of saliva. Such compositions could provide information regarding any changes in saliva activities as a response towards any occurring periodontal tissue inflammation. ${ }^{13}$

This research results showed that the salivary flow rate of the periodontitis group is higher than the rate of the healthy periodontal group. The previous study stated that it was probably caused by an inflammation, which caused a stimulation in the innervation of salivary glands, therefore increasing saliva secretion. This finding was similar with previous research which suggested that patients who experienced increment in saliva flow rate has a higher risk of getting periodontitis disease. ${ }^{9}$ The previous study showed different findings due to the small number of healthy respondents involved in the study. Those study also stated that salivary flow could vary due to gender, age, collection method, temperature, diurnal changes, diet and genetics. An increase in saliva flow rate could be in part attributed to an increase in gingival crevicular fluid and body's mechanism by increasing the saliva flow rate to deliver inflammatory mediators and immune cells to the site of infection. ${ }^{14}$

From the current research results, it can be seen that there were significant differences in calcium levels of the healthy periodontal group and the periodontitis group. The previous study suggested that it was possibly caused by concentrated calcium in saliva, indicating the severity and development of periodontal disease. ${ }^{15}$ This finding was similar with the previous study which stated that calcium levels in periodontitis patients were increased because the minerals in the periodontal tissues were dissolved with the crevicular gingiva fluid due to possible damaged of periodontal tissues. Calcium in extracellular matrix periodontal tissue plays a role as cellsignalling and calcium source needed for teeth and periodontal. ${ }^{16}$ The calcium levels of periodontitis in the present study was higher than the standard reference value of salivary calcium. Previous research stated that the standard reference value of salivary calcium value is in the range $0.5-2.7 \mathrm{mmol} / \mathrm{L}$ while in the present study was $\pm 452 \mathrm{mmol} / \mathrm{L}$. This finding was consistent with the previous study, which stated that an elevated level of salivary calcium related to a higher bone loss and lower mineral density. ${ }^{17}$ Calcium in saliva has essential roles in forming calculus in supragingival and subgingival. ${ }^{9}$ Calculus acts as the first place of plaque accumulation. The accumulated plaque, in turn, may cause periodontal disease. Along with an increase of mineral contents in saliva, the saliva mass will be calcified and become calculus. ${ }^{9}$ Research by Prashaanti et al. ${ }^{18}$ showed that subjects who experience increment in calcium and phosphate levels as well as possessed high $\mathrm{pH}$ saliva have a higher risk of getting periodontitis.

From the data presented can be seen that there was a significant difference between the phosphate levels of both groups, where the phosphate level of the periodontitis group was higher than the phosphate level of the healthy periodontal group. The previous study stated that it was probably caused by an inflammation that increased saliva secretion and therefore resulted in increased inorganic ions in saliva, including phosphate. ${ }^{19}$ Patel et al. ${ }^{19}$ discovered that increased phosphate ions in periodontitis were caused by an increased inflammation activity and destructive activities in alveolar bone. Increased phosphate level in periodontitis patient probably because periodontitis condition affected subjects have increased intraoral mineralization capacity as their saliva may contain many factors, which may favour mineralisation. ${ }^{8}$

Furthermore, there was found a significant difference in bicarbonate levels of both groups in which the bicarbonate level of the periodontitis was higher than the level of the healthy periodontal group. Bicarbonate is one of the inorganic components found in saliva and serves as buffer saliva. ${ }^{20}$ Previous study stated that the 
amount of saliva secretion influences the capacity of buffer saliva. ${ }^{20}$ This finding was also supported by Merinda et al. ${ }^{21}$, which stated that bicarbonate ions concentration in saliva would be increased up to $50 \mathrm{mmol} / \mathrm{L}$ when stimulated. ${ }^{21}$

The salivary flow rate was found to be correlated with calcium, phosphate and bicarbonate levels. The increment of the rate was caused by periodontitis which increased the inorganic compositions in saliva. This finding was similar with the previous research which stated that the saliva flow rate contributes to the formation of calculus and periodontal disease. Periodontitis patients with more considerable calculus accumulation have higher calcium level in their saliva than the average. ${ }^{19}$

\section{CONCLUSION}

The salivary ions levels and salivary flow rate of the healthy respondents are different periodontitis patients.

\section{REFERENCES}

1. National Institute of Health Research and Development (NIHRD). Indonesia Basic Health Research (RISKESDAS) 2012-2013. Jakarta: Ministry of Health of the Republic of Indonesia; 2013.

2. Data and Information Centre. Indonesia Health Profile. Jakarta: Ministry of Health of Republic of Indonesia; 2013.

3. Newman MG, Takei HH, Klokkevold PR, Carranza FA. Carranza's clinical periodontology. $11^{\text {th }}$ ed. St. Louis: Saunders-Elsevier; 2012.

4. Hajishengallis G. Immunomicrobial pathogenesis of periodontitis: Keystones, pathobionts, and host response. Trends Immunol. 2014; 35(1): 3-11. DOI: 10.1016/j. it.2013.09.001

5. Kallapur B, Ramalingam K, Bastian, Mujib A, Sarkar A, Sethuraman S. Quantitative estimation of sodium, potassium and total protein in saliva of diabetic smokers and nonsmokers: A novel study. J Nat Sci Biol Med. 2013; 4(2): 341-5. DOI: 10.4103/0976$\underline{9668.117006}$

6. Pfaffe T, Cooper-White J, Beyerlein P, Kostner K, Punyadeera C. Diagnostic potential of saliva: Current state and future applications. Clin Chem. 2011; 57(5): 675-87. DOI: $10.1373 /$ clinchem.2010.153767

7. Kumar B, Kashyap N, Avinash A, Chevvuri R, Sagar MK, Shrikant K. The composition, function and role of saliva in maintaining oral health: A review. Int J Contemp Dent Med Rev. 2017; 2017: DOI: 10.15713/ins.ijcdmr.121

8. Rajesh KS, Zareena, Hegde S, Kumar MSA. Assessment of salivary calcium, phosphate, magnesium, $\mathrm{pH}$, and flow rate in healthy subjects, periodontitis, and dental caries. Contemp Clin Dent. 2015; 6(4): 461-5. DOI: 10.4103/0976-237X.169846

9. Rane MV, Suragimath G, Varma S, Zope SA, Ashwinirani SR. Estimation and comparison of salivary calcium levels in healthy controls and patients with generalized gingivitis and chronic periodontitis. J Oral Res Rev. 2017; 9(1): 12-5. DOI: $10.4103 /$ jorr.jorr

10. Kim JJ, Kim CJ, Camargo PM. Salivary biomarkers in the diagnosis of periodontal. $\mathrm{J}$ Calif Dent Assoc. 2013; 41(2): 119-24.

11. Patil PB, Patil BR. Saliva: A diagnostic biomarker of periodontal disease. J Indian Soc Periodontol. 2011; 15(4): 310-7. DOI: 10.4103/0972-124X.92560

12. Nassar M, Hiraishi N, Islam MS, Otsuki $M$, Tagami J. Age-related changes in salivary biomarkers. J Dent Sci. 2014; 9(1): 85-90. DOI: $10.1016 / j . j d s .2013 .11 .002$

13. Bezerra Junior AA, Pallos D, Cortelli JR, Saraceni CHC, Queiroz CS. Evaluation of organic and inorganic compounds in the saliva of patients with chronic periodontal disease. Rev Odonto Ciênc. 2010; 25(3): 234-8. DOI: 10.1590/S1980-65232010000300003

14. Mbabali M, Mulli TK, Wagaiyu E. Salivary flow rate in adult and its relationship with chronic periodontitis. J Dent Oral Hyg. 2016; 8(7): 3742. DOI: $10.5897 /$ JDOH2016.0199

15. Yao SG, Fine JM. The potential role of systemic calcium in periodontal disease. Dent Open J. 2015; 2(5): 125-31. DOI: 10.17140/DOJ-2-123

16. Kurniawati I, Pujiastuti P, Dharmayanti AWS. Kadar kalsium (Ca) dalam cairan krevikular gingiva pada penderita periodontitis kronis. Odonto Dent J. 2015; 2(2): 8-13. DOI: 10.30659/odj.2.2.11-16

17. Gupta VV, Chitkara N, Gupta HV, Singh A, 
Gambhir RS, Kaur H. Comparison of salivary calcium level and ph in patients with aggressive periodontitis and healthy individuals: A clinico-biochemical study. Oral Health Dent Manag. 2016; 15(2): 122-6.

18. Prashaanthi N, Gayathri R, Vishnupriya V. A study on association of salivary calcium and phosphate in oral health. J Pharm Sci Res. 2016; 8(7): 623-6.

19. Patel RM, Varma S, Suragimath G, Zope S. Estimation and comparison of salivary calcium, phosphorous, alkaline phosphatase and ph levels in periodontal health and disease: A cross-sectional biochemical study. J Cinical Diagn Res. 2016; 10(7): 58-61. DOI: $10.7860 /$ JCDR/2016/20973.8182
20. Hervina H. Peningkatan kadar bikarbonat (HCO3-) saliva akibat stimulasi mekanis dan kimia. National Seminar Proceeding University of Mahasaraswati. In: Prosiding Seminar Nasional Hasil Penelitian. Proceedings of "Inovasi IPTEKS Perguruan Tinggi untuk Meningkatkan Kesejahteraan Masyarakat" Conference; 2016 August 29-30; Denpasar, Indonesia. Denpasar: Institute of Research and Community Service; 2016.

21. Merinda W, Indahyani DE, Rahayu YV. The correlation between salivary $\mathrm{pH}$ and buffer capacity with caries index of students in SLB-A Bintoro Jember [research report]. Jember: University of Jember; 2013. 